\title{
PENGARUH MINYAK KAYU PUTIH (Melaleuca leucadendron L.) DAN MINYAK SEREI (Cymbopogon nardus L.) SERTA CAMPURANNYA TERHADAP TANGKAPAN LALAT BUAH BACTROCERA
}

\author{
Oleh \\ Fitri Aulani, I Putu Artayasa, Muh. Liwa Ilhamdi \\ (Laboratorium Biologi FKIP Unram)
}

\begin{abstract}
ABSTRAK
Indonesia memiliki banyak jenis tanaman terutama jenis tanaman buah-buahan, tetapi terdapat kendala dalam produksi buah-buahan karena serangan hama atau organisme pengganggu tumbuhan (OPT) seperti lalat buah Bactrocera. Berbagai cara dilakukan untuk menangani serangan lalat buah seperti penggunaan atraktan dari tumbuhan. Penelitian ini bertujuan untuk mengetahui pengaruh minyak Kayu Putih (Malaleuca leucadendron L.) dan minyak Serei (Cymbopogon nardus L.) serta campurannya terhadap tangkapan lalat buah. Jenis penelitian adalah penelitian eksperimen. Data yang diperoleh dianalisis menggunakan uji Varians satu arah pada taraf nyata $5 \%$. Hasil analisis data menunjukkan $\mathrm{F}_{\text {hitung }}>\mathrm{F}_{\text {tabel }}$ artinya, pemberian minyak kayu putih (Malaleuca leucadendron L.) dan minyak Serei (Cymbopogon nardus L.) serta campurannya berpengaruh terhadap tangkapan lalat buah, dan dilanjutkan dengan Uji Tukey pada taraf nyata $0,05 \%$ untuk melihat perbedaan pengaruh masingmasing perlakuan, Hasil analisis disimpulkan bahwa pemberian minyak kayu putih (Malaleucaleucadendron L) dan minyak serei (Cymbopogon nardus L.) serta campurannya berpengaruh terhadap tangkapan lalat buah.
\end{abstract}

Kata-kata Kunci : Kayu Putih (Melaleuca leucodendron L.), Serei (Cymbopogon nardus L.), Atraktan, Lalat Buah, Bactrocera

\begin{abstract}
Indonesia has so numerous species of plants especially for the species of fruit plants, but there is a problem which the total of fruit production caused by the pest of fruit flies. A number of methods have been used to solve the problem such as by using the plants atractan. This an experimental research was conducted to determine the effect of Eucalyptus oil (Melaleuca leucodendron L.), Lemongrass oil (Cymbopogon nardus L.), and their mixtures in catching of Bactrocera fruit flies. The data of this research were analyzed by using one-way variance test on the real level of $0,05 \%$. Result of data

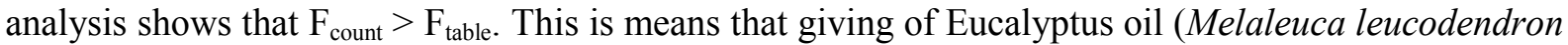
L.), Lemongrass oil (Cymbopogon nardus L), and their mixtures significantly influenced in catching number of the Bactrocera fruit flies. The data analysis was followed by Tukey tes at the real level of $5 \%$ to see how the different effect of each treatment. Based on the result of data analysis. This research concluded that both Eucalyptus oil (Melaleuca leucodendron L.), and Lemongrass oil (Cymbopogon nardus L.) were significantly influence the catching number of fruit flies.
\end{abstract}

Key words: Eucalyptus (Melaleuca leucodendron L.), Lemongrass (Cymbopogon nardus L.) Atractant, Bactrocera Fruit flies. 


\section{PENDAHULUAN}

Indonesia merupakan negara tropik yang memiliki keanekaragaman sumber daya alam hayati yang besar. Negara dengan letak astronomi yang memiliki curah hujan yang tinggi memungkinkan banyak jenis tanaman dapat tumbuh dan berkembang dengan baik, terutama dari jenis tanaman buah-buahan yang melimpah dan ditemukan diberbagai pelosok wilayah Indonesia. Buah-buahan merupakan makanan yang kaya kandungan serat, vitamin dan mineral yang dibutuhkan tubuh dalam membantu proses metabolisme serta dapat dimanfaatkan sebagai obat atau bahan baku obat.

Buah-buahan merupakan salah satu komoditi andalan pertanian yang menghidupi ribuan petani buah di Indonesia. Salah satu kendala utama dalam produksi buah-buahan di Indonesia bahkan dunia adalah hama atau organisme pengganggu tumbuhan (OPT)lalat buah (Anonim, 2010).

Lalat buah merupakan salah satu hama pada tanaman hortikultura, lebih dari 100 jenis tanaman hortikultura menjadi sasaran serangannya. Di Indonesia, lalat buah dikenal sebagai hama sejak tahun 1920 dan telah dikabarkan menyerang pertanaman mangga di Pulau Jawa. Berlanjut pada tahun 1938 lalat buah juga dikabarkan telah menyerang pertanaman cabai, jambu, belimbing dan sawo (Anonim, 1999 dalam Sarjan, 2010).

Lalat buah adalah organisme yang memiliki ovopositor dibagian posterior tubuhnya, dan ovopositor ini dimiliki oleh lalat buah betina, yang digunakan sebagai alat untuk meletakkan telurnya pada lapisan epidermis daging buah. Ketika telur menetas menjadi larva maka larva tersebut akan memakan daging buah hingga warna dan daging buah menjadi jelek dan berbelatung. Buah yang terserang lalat buah terkadang tampak sehat dan utuh dari luar tetapi bila dikupas di dalamnya busuk dan mengandung larva lalat dan tidak dapat dikonsumsi lagi.
Menurut Iskandar (2005), serangga pada buah muda menyebabkan buah rontok, sedangkan pada buah yang telah tua menyebabkan buah menjadi busuk dan berbelatung.

Kerugian yang diakibatkan lalat buah dapat ditinjau dari segi kuantitatif dan kualitatif. Secara kuantitatif serangan lalat buah mengakibatkan berkurangnya produksi buah, sedangkan secara kualitatifnya yaitu buah yang cacat berupa bercak busuk, berlubang yang akhirnya kurang diminati oleh konsumen, sehingga menurunkan daya saing komoditas hortikultura dipasar global. Ekspor buah mangga Indonesia pernah ditolak oleh negara tujuan dengan alasan mengandung larva lalat buah yang dapat merusak daging buah, hingga buah menjadi busuk (Kuswadi 2001 dalam Sarjan 2010).

Berkaitan dengan hal tersebut berbagai cara dilakukan untuk mengendalikan serangan lalat buah, beberapa diantaranya adalah menggunakan tehnik konvensional dan tehnik modern. Tehnik konvensional yang umum dilakukan dengan membungkus buah menggunakan plastik, namun tehnik ini dirasa kurang efektif, karena hanya bisa dilakukan untuk lahan yang kecil, tidak untuk lahan yang berukuran puluhan hektar, maka banyak petani yang beralih menggunakan tehnik modern. Insektisida bahan kimia sintetis menjadi salah satu pilihan alternatif karena dianggap lebih efektif dalam menangani hama serangga, sifatnya yang beracun dapat mempengaruhi pertumbuhan dan perkembangan serangga hingga pada akhirnya serangga itu mati, namun penggunaan pestisida kimia sintetis justru makin meningkatkan residu pestisida pada buah. Tingginya risidu pestisida pada buah dapat berakibat fatal seperti resistensi hama terhadap insektisida, resurgensi atau matinya organisme bukan sasaran, dan residu insektsida yang membahayakan apabila dikonsumsi oleh manusia. Seiring dengan 
berkembangnya ilmu pengetahuan, ditemukan alternatif lain dalam pengendalian hama insekta terutama lalat buah yaitu dengan menggunakan bahan bioinsektisida sebagai solusi pemecahan masalah penggunaan insektisida dari bahan kimia sintetik, aplikasi bioinsektisida umumnya tidak menimbulkan residu sehingga aman bagi kesehatan manusia (Anonim, 2010).

Bioinsektisida yang digunakan bisa berasal dari minyak atsiri tanaman yang dimanfaatkan sebagai atraktan pengendali hama insekta khususnya lalat buah. Indonesia merupakan salah satu negara penghasil minyak atsiri terpenting di dunia, ada sekitar 40 jenis tanaman penghasil minyak atsiri, beberapa diantaranya dapat digunakan sebagai pestisida nabati yaitu dari daun wangi (Melaleuca bracteata) dan selasih (Ocimum spp.) (Kardinan, 2005).

Tanaman yang biasa digunakan sebagai pestisida alami biasanya memiliki kandungan metil eugenol yang bermanfaat sebagai pemikat lalat buah. Metil eugenol dalam tanaman bermanfaat sebagai pemikat lalat buah serta memiliki kandungan bahan alami yang ramah lingkungan, dan telah terbukti efektif sebagai atraktan untuk menangkap lalat buah. Atraktan dapat digunakan untuk mengendalikan lalat buah dalam tiga cara, yaitu: (1) mendeteksi atau memantau populasi lalat buah; (2) menarik lalat buah untuk kemudian diperangkap; dan (3) mengacaukan lalat buah dalam perkawinan, berkumpul, dan cara makan.

Metil eugenol $\left(\mathrm{C}_{12} \mathrm{H}_{24} \mathrm{O}_{8}\right)$ merupakan zat yang unik karena zat ini merupakan food lure atau dibutuhkan oleh lalat buah jantan untuk dikonsumsi. Radius aroma dari metil eugenol mencapai 20-100 m, tetapi jika dibantu angin bisa mencapai $3 \mathrm{~km}$. Didalam tubuh lalat buah jantan, metil eugenol diproses menjadi zat pemikat (sex pheromone) yang akan berguna dalam proses perkawinan, dimana lalat buah jantan mengeluarkan aroma yang berfungsi sebagai daya pikat seksual (sex pheromone) (Kardinan, 2005).

Metil eugenol dikenal sebagai senyawa semio chemicals yang dapat mempengaruhi tingkah laku hewan serangga, seperti perilaku mencari makanan, meletakkan telur, hubungan seksual dan lainnya. Menurut Kardinan (2007) mengatakan bahwa metil eugenol $\left(\mathrm{C}_{12} \mathrm{H}_{24} \mathrm{O}_{8}\right)$ adalah bahan semio chemicals merupakan atraktan lalat buah yang dapat merangsang olfactory (alat sensor) serangga.

Penelitian ini menggunakan bahan bioinsektisida yang berasal dari tanaman minyak kayu putih (Melaleuca leucadendron L.) dan minyak serei (Cymbopogon nardus L.) serta campuran keduanya, untuk melihat hasil tangkapan lalat buah. Dipilihnya (Malaleuca leucadendron L.) yaitu karena tanamanini memiliki kandungan metil eugenol sekitar $80 \%$, selain itu tanaman minyak kayu putih juga bisa ditemukan pada daerah yang relatif kering sehingga tidak sulit untuk didapatkan. Minyak serei (Cymbopogon nardus L.) dipilih sebagai atraktan karena tanaman ini selain memiliki kandungan eugenol, minyak serei juga memiliki kandungan bahan hayati hasil metabolisme tumbuhan yang diduga dapat berperan ganda dalam mengusir serta menangkap serangga. Penggunaan dua bahan campuran dilakukan dengan alasan jika campuran bersifat sinergis, maka dapat membantu dalam memperkecil penggunan konsentrasi atraktan.

\section{BAHAN DAN METODE}

Penelitian ini dilaksanakan di kebun Lingkungan Marong Jamak, Kelurahan Karang Baru, Mataram. Waktu penelitian berlangsung selama 9 hari (3 kali pengulangan pada3 hari yang berbeda) di bulan juni tahun 2012 .

Pengujian dilakukan dengan menggunakan Rancangan Rancangan Acak Kelompok (RAK) yang terdiri atas enam 
perlakuan dan setiap perlakuan diulang sebanyak empat ulangan. Adapun perlakuan adalah sebagai berikut:

Kontrol $(\mathrm{A})=$ Kontrol
perlakuan atraktan).
$\begin{aligned} & \text { Perlakuan }(\mathrm{B})= \\ & \text { atraktan minyak Serei. }\end{aligned}$

Perlakuan $(\mathrm{C})=$ Perangkap dengan atraktan minyak kayu putih.

$\begin{array}{ll}\text { Perlakuan } & \text { (D) }=\text { Perangkap dengan }\end{array}$ atraktan campuran minyak Serei dengan minyak Kayu Putih.

Dalam tehnik pengambilan data, alat yang dipergunakan adalah berupa botol bekas air mineral yang berukuran $1.500 \mathrm{ml}$ yang lehernya berbentuk kerucut. Bagian sisi-sisi botol dilubangi sebagai jalan masuk lalat buah. Pada bagian tengah tutup botol dilubangi sebagai jalan masuk kawat yang berfungsi sebagai tempat pengkait kapas, sisa kawat lainnya dijadikan sebagai alat pengkait untuk peletakkan perangkap, kemudian bagian sisi botol diberikan perekat lalat dengan bahan perekat yang tidak berwarna dan berbau.

\section{Pemberian Perlakuan Pada Perangkap}

Ada tiga perlakuan yang diberikan pada masing-masing perangkap, yaitu untuk perangkap pertama hanya ditetesi air (tanpa pemberian perlakuan menggunakan atraktan pada kapasnya), untuk perangkap kedua diberikan perlakuan dengan tetesan minyak serei sebanyak 8 tetes pada kapasnya, perangkap ketiga diberikan perlakuan dengan tetesan minyak kayu putih sebanyak 8 tetes pada kapasnya, dan perangkap yang keempat diberikan perlakuan dengan tetesan minyak campuran antara minyak serei dengan minyak kayu putih sebanyak 8 tetes pada kapasnya. Campuran minyak serei dan minyak kayu putih menggunakan volume yang sama, yaitu sebanyak 8 tetes untuk masing-masing minyak yang akan dicampurkan, sementara itu masing-masing perangkap sudah diberikan air pada dasar perangkapnya tanpa menyentuh kapas. Minyak serei dan minyak kayu putih berfungsi sebagai senyawa pemikat yang bekerja sebagai penarik lalat buah.

\section{Peletakkan Perangkap}

Perangkap diletakkan pada pohon dengan ketinggian 1-1,5 $\mathrm{m}$ dari permukaan tanah, dengan jarak antar perangkap $10 \mathrm{~m}$. Perangkap diletakkanpada pagi hari sekitar jam 08.00 wita dan dibiarkan selama 3 hari, kemudian setelah 3 hari perangkap diambil pada jam yang sama sekitar 08.00 wita. Pengulangan dilakukan sebanyak 3 kali pada 3 hari yang berbeda, setiap pengulangan dilakukan pertukaran peletakkan perangkap secara acak sederhana dan pemberian tetesan atraktan yang baru.

\section{HASIL DAN PEMBAHASAN 1. Hasil}

Pengumpulan data berlangsung selama sembilan hari (tiga kali pengulangan pada tiga hari yang berbeda) di kebun Lingkungan Marong Jamak, Kelurahan Karang Baru, Mataram, pada bulan Juni 2012. Lalat buah yang diperoleh ada dua jenis spesies, yaitu Bactrocera dorsalis Handel (jantan dan betina) dan Bactrocera umbrosus Fibricus (jantan) (Gambar 1). 


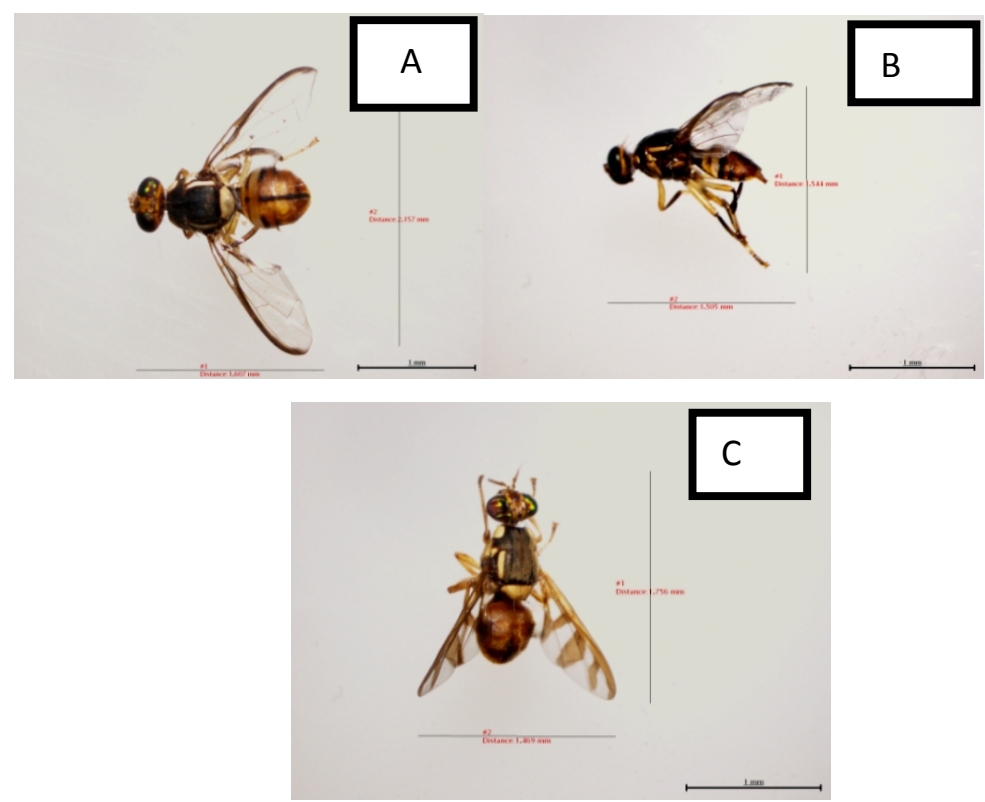

Gambar 1. Bactrocera dorsalis Handel jantan (A), Bactrocera dorsalisHandel betina (B), Bactrocera umbrosus Fibricus jantan (C)

Secara umum lalat buah Bactrocera dorsalis Handel memiliki sayap yang tidak berwarna, dan pada bagian abdomennya terdapat pita hitam berbentuk huruf $\mathrm{T}$, sedangkan lalat buah spesies Bactrocera umbrosus Fabricus secara umum memiliki sayap yang berwarna dengan tiga garis nyata melintang, sedangkan bagian abdomen
Bactrocera umbrosus Fibricus terdapat garis medial yang warnanya sering berubah.

Berdasarkan data jumlah tangkapan lalat buah yang diperoleh setelah pemberian perlakuan dengan atraktan minyak kayu putih (Malaleuca leucadendron L.) dan minyak serei (Cymbopogon nardus L.) serta campuran minyak kayu putih dan minyak serei pada perangkap (Tabel 1).

Tabel 1. Data Hasil Jumlah Tangkapan Lalat Buah setelah Diberi Perlakuan Pemberian Atraktan Minyak Kayu Putih (Malaleucaleucadendron L.) dan Minyak Serei (Cymbopogon nardus L.) serta Campuran di Kebun Marong Jamak, Karang Baru, Mataram

\begin{tabular}{|c|c|c|c|c|c|}
\hline \multirow{2}{*}{ Ulangan } & \multicolumn{5}{|c|}{ Jumlah Tangkapan Lalat Buah } \\
\cline { 2 - 5 } & $\begin{array}{c}\text { Kontrol } \\
\text { (A) }\end{array}$ & $\begin{array}{c}\text { Perlakuan } \\
\text { (B) }\end{array}$ & $\begin{array}{c}\text { Perlakuan } \\
\text { (C) }\end{array}$ & $\begin{array}{c}\text { Perlakuan } \\
\text { (D) }\end{array}$ & \multirow{2}{*}{ Jumlah } \\
\hline 1 & 0 & 3 & 0 & 1 & $\mathbf{4}$ \\
2 & 0 & 4 & 4 & 3 & $\mathbf{1 1}$ \\
3 & 0 & 6 & 5 & 2 & $\mathbf{1 3}$ \\
Jumlah & $\mathbf{0}$ & $\mathbf{1 3}$ & $\mathbf{9}$ & $\mathbf{6}$ & $\mathbf{2 8}$ \\
Rata-rata & & & & 2 & \\
$(\bar{y})$ & 0 & 4,33 & 3 & & \\
\hline
\end{tabular}


Secara kuantitatif, persentase jumlah tangkapan yang diperoleh pada masingmasing perangkap berbeda. Pada perangkap A (kontrol) sebesar 0\%, perangkap B (atraktan minyak serei) sebesar 46\%, perangkap $\mathrm{C}$ (atraktan minyak kayu putih) sebesar $10 \%$, dan perangkap D (atraktan campuran antara minyak serei dan minyak kayu putih) sebesar 7\%. Adapun jumlah lalat buah Bactrocera dorsalis Handel jantan yang diperoleh ada 24 individu dan yang betina ada 2 individu, sedangkan lalat buah spesiesBactrocera umbrosus Fibricus jantan yang diperoleh ada 2 individu (Gambar 2).

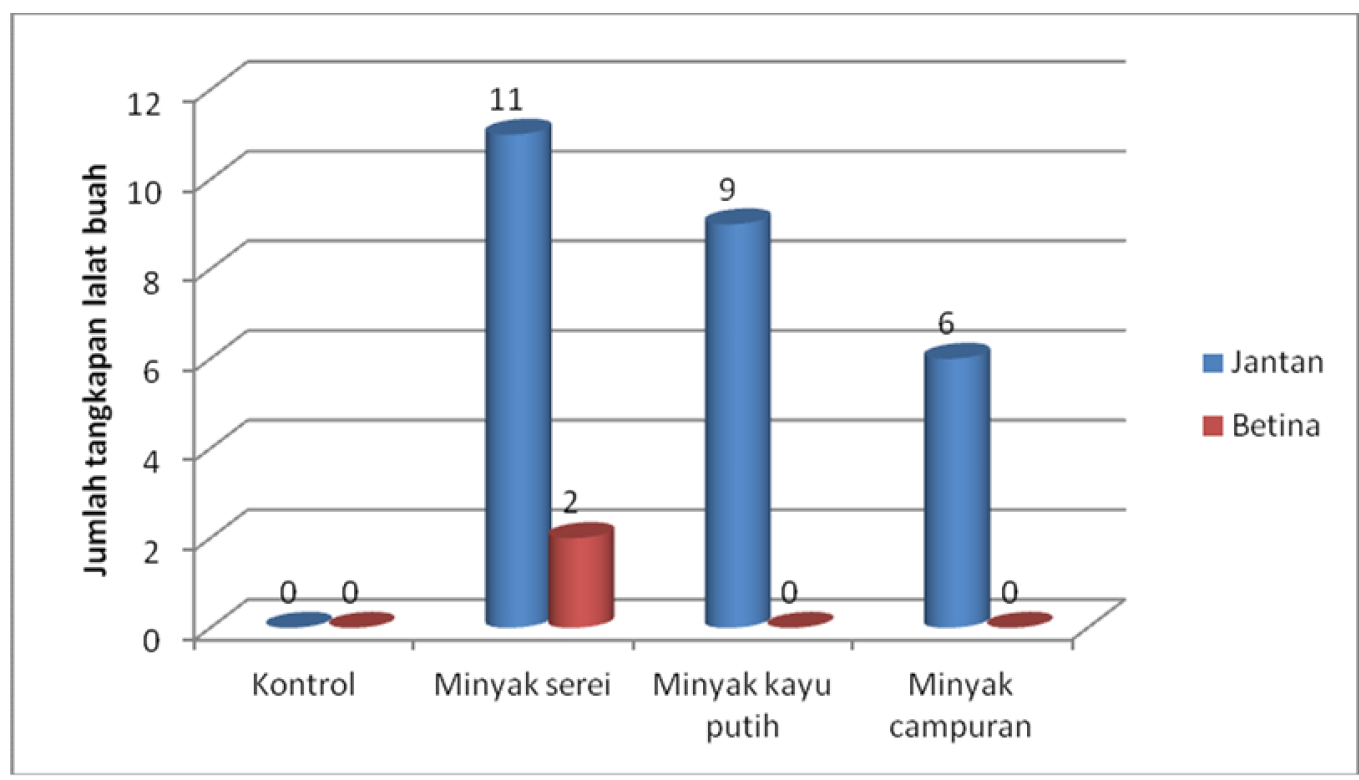

Gambar 2. Jumlah Tangkapan Lalat Buah (Jantan dan Betina) di Kebun Lingkungan Marong Jamak, Kelurahan Karang Baru, Mataram Tahun 2012

individu/perangkap/hari, pada perangkap C

Berdasarkan nilai rata-rata hasil tangkapan, perangkap A (kontrol) diperoleh nilai rata-ratanya 0 individu/perangkap/hari, karena tidak ada hasil tangkapan lalat buah yang diperoleh, perangkap $\mathrm{B}$ dengan perlakuan menggunakan (atraktan minyak Serei) diperoleh nilai rata-rata 4,33 dengan perlakuan menggunakan (atraktan minyak Kayu putih) diperoleh nilai rata-rata 3 individu/perangkap/hari, dan untuk perangkap D dengan perlakuan (atraktan minyak campuran) antara minyak Serei dengan Kayu Putih diperoleh nilai rata-rata 2 individu/perangkap/hari (Gambar 3). 


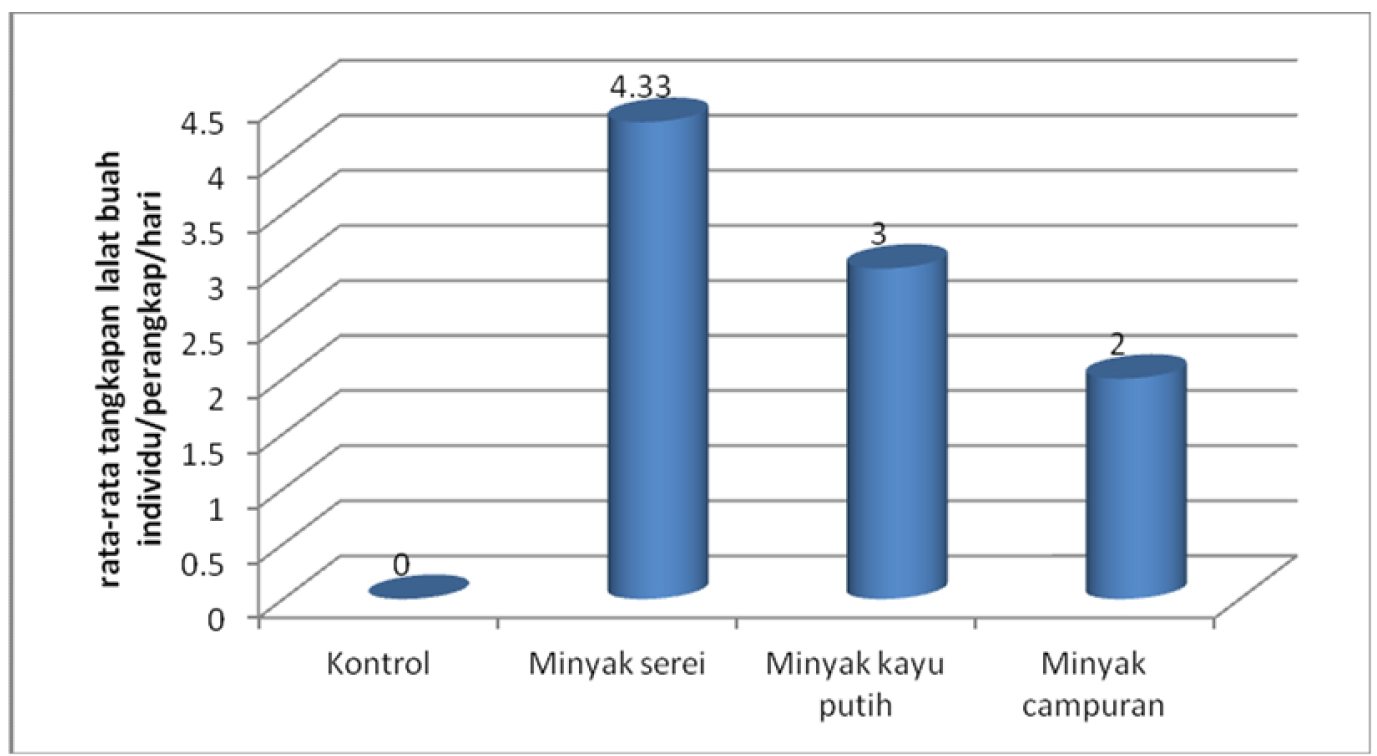

Gambar 3. Rata-rata jumlah tangkapan lalat buah di kebun Lingkungan Marong Jamak, Kelurahan Karang Baru, Mataram Tahun 2012

nardusL) serta campurannya terhadap

Untuk mengetahui pengaruh minyakminyak kayu putih (Melaleuca Leucadendron L) dan serei (Cymbopogon tangkapan lalat buah dilakukan uji statistik dengan menggunakan analisis varians satu arah pada taraf nyata 5\% (Tabel 2).

Tabel 2. Hasil Analisis Varian (ANOVA) jumlah tangkapan lalat buah setelah diberi perlakuan atraktan minyak kayu putih, dan minyak serei serta campurannya di kebun Marong Jamak, Karang Baru Mataram

\begin{tabular}{llllll}
\hline Sumber Variasi & $\mathrm{db}$ & $\mathrm{JK}$ & $\mathrm{KT}$ & $F_{\text {hitung }}$ & $F_{\text {tabel }} 5 \%$ \\
\hline Perlakuan & 3 & 30 & 10 & 6,32 & 4,76 \\
Ulangan & 2 & 11,2 & 5,6 & & \\
Galat & 6 & 9,5 & 1,58 & & \\
Total & 11 & & & & \\
\hline
\end{tabular}

Hasil analisis data menunjukkan $\mathrm{F}_{\text {hitung }}=$ 6,32dan $F_{\text {tabel }}=4,76$, maka diperoleh data $\mathrm{F}_{\text {hitung }}>\mathrm{F}_{\text {tabel. }}$ Hasil analisis ini menunjukkan bahwa $\mathrm{Ha}$ diterima, artinya pemberian minyak kayu putih dan minyak serei serta campuranya berpengaruh terhadap tangkapan lalat buah.
Uji BNJ sebagai uji lanjutan digunakan untuk mengetahui perbedaan pengaruh antar perlakuan pada setiap perangkap berdasarkan nilai rata-rata hasil tangkapan lalat buah yang disusun dari nilai rata-rata perlakuan terkecil hingga yang terbesar.

Tabel 3. Hasil uji (BNJ) jumlah tangkapan lalat buah setelah diberi perlakuan atraktan minyak kayu putih, dan minyak serei dan campurannya di kebun Marong Jamak, Karang Baru Mataram 


\begin{tabular}{lcc}
\hline Perlakuan & Rata-rata & Notasi atas $\boldsymbol{B N J _ { 0 , 0 5 }}$ \\
\hline A (Kontrol) & 0 & $\mathrm{a}$ \\
D (M. Kayu Putih) & 2 & $\mathrm{ab}$ \\
C (M. Campuran) & 3 & $\mathrm{ab}$ \\
B (M. Serei) & 4,33 & $\mathrm{~b}$ \\
$B N J_{0,05}$ & 3,16 &
\end{tabular}

Data hasil perhitungan $B N J_{0,05 \%}$ (Tabel 3) yang diperoleh dapat disimpulkan, bahwa perangkap dengan perlakuan A (kontrol), D (Minyak Campuran), dan C (Minyak Kayu Putih) mempunyai notasi huruf yang sama yaitu "a", yang artinya perangkap dengan perlakuan A (kontrol), D (Minyak Campuran), dan C (Minyak Kayu Putih) tidak berbeda nyata, begitu pula antara perangkap dengan perlakuan $\mathrm{D}, \mathrm{C}$, dan $\mathrm{B}$ yang memiliki notasi yang sama yaitu "b" yang artinya perangkap dengan perlakuan yang memiliki notasi yang sama, memiliki potensi yang sama sebagai pemikat lalat buah.

\section{Pembahasan}

Pada proses penelitian diperoleh dua jenis spesies lalat buah yang tertangkap pada perangkap lalat buah, yaitu dari spesies Bactrocera dorsalis (Handle) dan Bactrocera umbrosus (Fibricus). Hasil tangkapan lalat buah Bactrocera dorsalis Handel yang diperoleh lebih banyak dari lalat buah Bactrocera umbrosus Fibricus, hal ini dilihat dari jumlah tangkapan untuk masing-masing jenis spesies yang berbeda. Jumlah lalat buah Bactrocera dorsalis Handel yang diperoleh ada 26 individu, sedangkan lalat buah spesiesBactroceraumbrosus Fibricus yang diperoleh ada 2 individu.

Jumlah individu tiap jenis spesies yang tertangkap pada perangkap lalat buah bisa diakibatkan oleh faktor jenis tanaman buah yang ada disekitar kebun. Bactrocera dorsalis Handel tertangkap lebih banyak karena mempunyai lebih banyak jenis tanaman inang. Menurut Bangun (2009) ada 20 jenis buah yang diserang oleh lalat buah Bactrocera dorsalis Handle, beberapa diantaranya buah jeruk, belimbing, mangga, jambu biji, jambu air, pisang, dan cabai merah, sedangkan Bactrocera umbrosus Fibricus biasanya menyerang pertanaman nangka dan rambutan. Hal ini sesuai dengan keadaan di lokasi penelitian di kebun lingkungan Marong Jamak, Kelurahan Karang Baru, Mataram, ada beberapa jenis tanaman buah yang tumbuh diseputaran kebun tersebut seperti pohon mangga, pisang, belimbing, jambu biji, nangka, rambutan dan sawo.

Berdasarkan hasil tangkapan tiap jenis spesies yang diperoleh, ditemukan ada dua jenis (kelamin) lalat buah dalam spesies yang sama, yaitu lalat buah Bactrocera dorsalis Handel jantan dan Bactrocera dorsalis Handel betina. Bactrocera dorsalis Handel jantan yang diperoleh ada 24 individu dan yang betina ada 2 individu, sedangkan lalat buah Bactrocera umbrosus Fibricus hanya ditemukan jantan saja sebanyak 2 individu. Pengendalian hama lalat buah dengan atraktan biasanya hanya mampu digunakan untuk menarik lalat buah jantan saja, karena sifat atraktan pada umumnya bersifat paraferomon, yaitu 
senyawa yang aromanya sama dengan yang dikeluarkan oleh lalat buah betina, terutama atraktan yang terbuat dari bahan kimia sintetis, namun dalam penelitian ini ada dua individu lalat buah betina yang diperoleh, yang ditemukan pada perangkap dengan perlakuan menggunakan atraktan dari minyak serei. Menurut Zulfitriany (2000) dalam Zulfitriany (2004), berdasarkan hasil penelitian yang dilakukan di Laboratorium Hama dan Penyakit Tumbuhan Universitas Hasanuddin, menunjukkan bahwa minyak sereh bersifat atraktan terhadap lalat buah baik jantan maupun betina.

Dilihat dari hasil tangkapan pada masing-masing perangkap berbeda berdasarkan nilai rata-ratanya, perangkap dengan perlakuan minyak serei memiliki nilai rata-rata yang lebih tinggi dari pada nilai rata-rata perangkap (kontrol) tanpa pemberian perlakuan atraktan, dan perangkap dengan atraktan minyak kayu putih, serta perangkap dengan atraktan minyak campuran antara minyak kayu putih dengan minyak serei. Perbedaaan hasil tangkapan bisa dipengaruhi karena adanya perbedaan perlakuan masing-masing perangkap.

Perangkap dengan perlakuan menggunakan Minyak kayu putih memiliki hasil tangkapan lebih rendah dari perangkap dengan perlakuan menggunakan tetesan minyak serei, hal ini mungkin dikarenakan karena minyak kayu putih (Malaleuca leucadendron Linn) yang meskipun diperkirakan memiliki kandungan eugenol sebesar $\pm 80 \%$, namun tingkat ketahanan aroma minyaknya tidak begitu tahan lama. Menurut Anonim (2012), komponen minyak esensial (Eucalyptol) kayu putih cepat menguap. hal ini terlihat berdasarkan hasil tangkapan disetiap jeda ulangan pada ulangan kedua dihari pertama, hari kedua dan hari ketiga sebelum ulangan ketiga dilakukan, hasil tangkapan terus mengalami penurunan, sedangkan pada minyak serei (Cymbopogon nardus Linn) meskipun kadar eugenolnya tidak sebesar pada minyak kayu putih, karena kandungan terbesar pada minyak serei wangi yaitu Sitronella dan geraniol, namun tingkat ketahanan aroma minyak serei wangi relatif lebih tahan lama dibandingkan minyak kayu putih, terlihat pada perangkap dengan perlakuan minyak serei terus didatangi lalat buah meskipun penelitian sudah tidak dilakukan. Menurut Sugati (1991) dalam Zulfitriany (2004) tanaman sereh wangi pada daun dan akarnya mengandung saponin, flavanoida dan polifenol. Saponin merupakan kelompok senyawa ter-penoid yang tidak mudah menguap (Harborne 1987 dalam Zulfitriany 2004). Selain itu bahan-bahan lain seperti alkohol, dan terpene yang terkandung pada minyak serei dianggap mampu menarik lalat buah. Menurut Anonim (2009) minyak serei mengandung campuran dari bahan hayati, termasuk di dalamnya aldehide, alkohol, ester, keton dan terpene. Bahan-bahan ini kemungkinan merupakan sisa metabolisme tumbuh-tumbuhan dan digunakan untuk menjalankan peran ganda, seperti menarik serangga atau mengusir serangga. Unsur yang mengandung aroma, kemungkinan terbentuk dalam hijau daun (Chloroplast) kemudian unsur tersebut bersatu dengan glukosa, menciptakan glukosida yang disalurkan ke seluruh tubuh tumbuhan. Sehingga aroma yang ditimbulkan oleh senyawa-senyawa tersebut diduga mempunyai daya tarik terhadap lalat buah.

Perangkap dengan perlakuan minyak campuran antara kayu putih dan serei memiliki nilai rata-rata hasil tangkapan lalat buah yang paling sedikit di antara perangkap dengan perlakuan pemberian tetesan minyak kayu putih dan serei, hal ini diduga karena minyak campuran antara minyak kayu putih dengan minyak serei bersifat antagonis, artinya sifat bahan aktif antara minyak saling menurunkan, hal ini dilihat pada hasil tangkapan yang mengalami penurunan. Menurut Kardinan, (2007) bahwa pencampuran dua jenis bahan kimia dapat bersifat antagonis (saling merugikan) atau sinergis (saling menguntungkan). 


\section{KESIMPULAN}

Berbasarkan hasil dan pembahasan penelitian ini dapat disimpulakn, bahwa pemberian minyak kayu putih (Malaleucaleucadendron L.) dan minyak serei (Cymbopogon nardus L.) serta campurannya berpengaruh signifikan terhadap hasil tangkapan lalat buah.

\section{DAFTAR PUSTAKA}

Anonim. 2009. Kayu Putih. Dikutipdari http://id.wikipedia.org/wiki/Kayu_p utih. Diakses pada tanggal 29 maret 2012.

Anonim. 2010. Bactrocera. Dikutip darihttp:

//id.m.wikipedia.org/Bactrocera.

Diakses pada tanggal 29 maret 2012.

Anonim. 2012. Khasiat Kayu Putih (Meialeucaleucadendra l.) Sebagai Tanaman Obat Herbal. Dikutip dari http://jamu.biologi.ub.ac.id/.

Diakses pada tanggal 29 maret 2012.

Bangun, D. A. 2009. Kajian Beberapa Metode Perangkap Lala Buah (Diptera; Tephritidae) Pada Pertanaman Jeruk Manis (Citrus spp.) di Desa Sukanalu Kabupaten Karo. Dikutip dari http://repository.usu.ac.id/bitstream/ .pdf. Diakses pada tanggal 29 maret 2012.

Iskandar, M. 2005. Cemara Hantu dan Selasih Berpotensi Mengendalikan Lalat Buah

Kardinan, A. 2005. Tanaman Penghasil Minyak Atsiri Komoditas Wangi Penuh Potensi. Jakarta: PT Agro Media Pustaka.
Kardinan, A. 2007. Pengaruh Campuran Beberapa Jenis Minyak Nabati Terhadap Daya Tangkap Lalat Buah. Bul. Littro (1): 60 - 66. Dikutip dari balittro.litbang.deptan.go.id/ind/ima ges/stories/.../6-lalatbuah.pdf.

Diakses pada tanggal 9 Januari 2012

Sarjan, M. 2010. Kelimpahan dan Komposisi Spesies Lalat Buah pada Lahan Kering di Kabupaten Lombok Barat. Dikutip dari http://fp.unram.ac.id/data/Sarjan.pdf - Diakses pada tanggal. Diakses pada tanggal 9 Januari 2012.

Zulfitriany, D. M., dkk. 2004. Pemanfaatan Minyak Sereh (Andropogon nardus l.) Sebagai Atraktan Berperekat Terhadap Lalat Buah (Bactroceraspp.) Pada Pertanaman Mangga. Dikutip dari http://pasca.unhas.ac.id/jurnal_pdf/. Diakses pada tanggal 9 Januari 2012. 